to absorb the conclusions of the senate the night before, and we decided it would only be fair to give the evaluators time to consider the implications," he says. The decision was deferred for two months.

Bulmahn says that Germany's new national ethics council, created last week by Chancellor Gerhard Schröder, should debate the issue of human embryonic stem-cell research. "New courses that cross long-established ethical boundaries, cannot be changed in a hurry," she says.

Wolf-Michael Catenhusen, state secretary for research, says: "The DFG can formulate its position as often as it wants, but this does not change public opinion - nor political opinion."

"It is very appropriate that Germany has approached embryonic stem-cell research slowly and carefully," says Brüstle. But he is surprised and disappointed that his research is still being held up. "The continual delays are starting to feel no different from rejection."

Winnacker declines to speculate on what would happen if the research ministry tried to instruct the DFG - whose independence is enshrined in statute not to fund embryonic stem-cell research. "I don't know," he says. "Political interference is something that has never happened in the 51 years of DFG history, so we have no precedent."

\title{
Birthday meeting bemoans low profile of science office
}

\section{Steve Nadis, Boston}

It may be 25 years old, but the White House Office of Science and Technology Policy (OSTP) has yet to establish a strong identity in Washington. That was one recurrent theme at a conference held on 1 May to celebrate the OSTP's anniversary.

John Porter, a science advocate and former Illinois congressman, told the meeting that most members of Congress "would be unlikely to have ever heard of the Office of Science and Technology Policy or to know the initials OSTP. They would probably recognize that the president has a science adviser, but few would be able to identify him or her."

Held at the Massachusetts Institute of Technology, the meeting attracted seven former presidential science advisers, including 91-year-old William Golden, who served as the first real science adviser to Harry Truman just after the Second World War. The position persisted in various forms before it was institutionalized in the 1976 law that established the OSTP as a permanent office, the director of which also serves as the president's science adviser.

Porter said that the low visibility of the OSTP placed an even stronger onus on scientists to step forward and make themselves

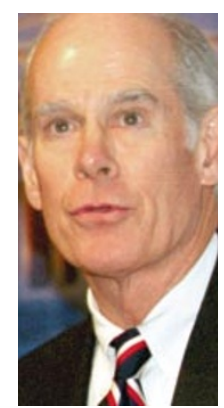

heard in policy debates. MIT president Charles Vest agreed, calling for a new generation of "citizen scientists to explain what we do and why it is important". Changes in education are needed to prepare scientists for this additional role, he said.

Some of the meeting's John Porter says organizers had hoped that scientists need to the new administration of be heard.

President George W. Bush would appoint a science adviser in time for the event, but it did not. Porter noted that Bush has already made decisions on matters such as the Kyoto Protocol and missile defence without input from a presidential science adviser or from the OSTP.

The lack of a science adviser at this stage of the administration is not unprecedented, meeting attendees were told, but it still concerned some of the speakers. Golden said it mattered "because science and technology runs through the fabric of so many issues on both domestic and foreign fronts. Functioning without a science adviser," he said, "is like playing baseball without a full team.”

\section{Plans for missile defence system perturb physicists}

\section{Irwin Goodwin, Washington}

The announcement by President George W. Bush that he plans to abandon the 1972 AntiBallistic Missile (ABM) treaty has been met with concern from leading US physicists.

The reasoning behind Bush's plan to move ahead rapidly with a new missile defence system for the United States and its allies was questioned by physicists at a recent meeting of the American Physical

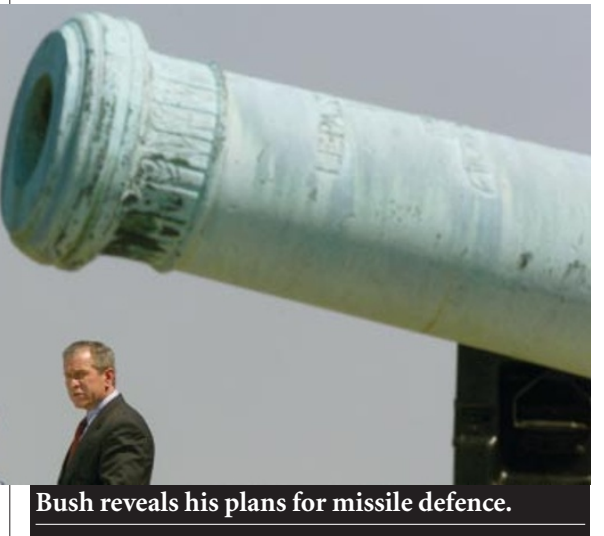

Society (APS) in Washington.

"The last thing the so-called rogue countries would do is launch against the United States, because of the instant retaliation that would result," Richard Garwin, a retired IBM physicist who has advised the US government on $\mathrm{ABM}$ and other technical issues, told the meeting.

Bush has so far offered few details about what his missile defence structure would look like, when it will be deployed or what it would cost. But he has said that the system would be "layered", meaning that it would involve attempts to intercept missiles at each of their flight stages - during launch, in orbit and during re-entry.

Garwin says that the best prospect of a working system is one that targets the missile during its boost phase, as it moves into orbit. The APS has set up a 12-member panel to look into the feasibility of this approach and deliver an unclassified report by the end of the year, in time to feed into Bush's decision on what systems to build.

The Clinton administration's far less ambitious plan called for a smaller system, with 100 missile interceptors based in Alaska and intended to protect against a limited attack by a 'rogue state'. The Congressional Budget Office estimated that Clinton's system would cost about $\$ 60$ billion to deploy.

Some analysts say that the United States has already spent about $\$ 60$ billion on missile defence over the past 50 years, including \$27 billion on President Ronald Reagan's Strategic Defense Initiative, with little to show in return.

Spending on missile defence this year is expected to top $\$ 4.9$ billion, making it the largest single programme in the defence department, even before the programme is expanded to meet Bush's objectives. Critics say that the Bush initiative is likely to cost $\$ 100$ billion or more.

Beneficiaries of the programme may include university scientists in fields such as optics and nanotechnology, but the great bulk of the expenditure will be in development, rather than scientific research, according to officials in the defence department. 